Available online on 20.08 .2020 at http://jddtonline.info
Open Access to Pharmaceutical and Medical Research

Open $\odot$ Access

Research Article

\title{
N-Acetylcystein has Potential Effect to Reduce Haematological Abnormalities in HIV/AIDS Patients Undergoing ARV Treatment
}

\author{
Filia Yuniza*1, Eddy Mart Salim², Nova Kurniati², Harun Hudari², Erial Bahar³ ${ }^{3}$, Agustian Dwi Putra², Sri Sulpha Siregar1, \\ Guntur Baruara1,
}

${ }^{1}$ Magister of Biomedical Science, Medical Faculty, Universitas Sriwijaya, Indonesia

${ }^{2}$ Department of Internal Medicine, Muhammad Hoesin Central Hospital, Indonesia

${ }^{3}$ Department of Biomedical Science, Medical Faculty, Universitas Sriwijaya, Indonesia

\section{ABSTRACT}

Aims: to determine the effect of NAC administration on hematological abnormalities in HIV/AIDS patients who are undergoing ARV treatment.

Method: This was a pilot study using a double blind randomized clinical trial. A total of 32 subjects who met the inclusion and exclusion criteria were divided into 2 groups, namely placebo and NAC. Subjects in the NAC group were given NAC at a dose of 3x200 mg/day, while the placebo group was given lactose at a dose of $3 \times 200 \mathrm{mg} /$ day. Each group was given treatment for 12 weeks. Before and after treatment, subjects were examined for hematologic parameters.

Results: Most of subjects had normal hematological features. NAC administration did not have a significant effect on the mean levels of Hb, $\mathrm{Ht}$, number of erythrocytes, leukocytes and platelets ( $>0.05$ ). However, NAC administration can reduce the degree of anemia and improve the condition of thrombocytopenia, leukopenia and lymphopenia.

Conclusion: NAC administration can reduce hematological abnormalities HIV/AIDS patients undergoing ARV treatment.

Keywords: ARV, Hematological abnormalities, HIV/AIDS, NAC.

Article Info: Received 21 June 2020; Review Completed 26 July 2020; Accepted 08 August 2020; Available online 20 August 2020

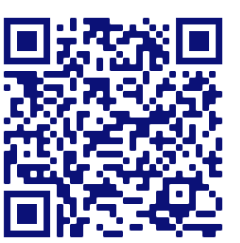

Cite this article as:

Yuniza F, Salim EM, Kurniati N, Hudari H, Bahar E, Putra AD, Siregar SS, Baruara G, N-Acetylcystein has Potential Effect to Reduce Haematological Abnormalities in HIV/AIDS Patients Undergoing ARV Treatment, Journal of Drug Delivery and Therapeutics. 2020; 10(4-s):197-200 http://dx.doi.org/10.22270/jddt.v10i4-s.4319

Filia Yuniza, Magister of Biomedical Science, Medical Faculty, Universitas Sriwijaya, Indonesia

\section{INTRODUCTION}

HIV infection is known to cause various disorders in the hematopoietic system. ${ }^{1}$ This condition is caused by various factors, including the direct effect of HIV infection. HIV infection causes disruption of cytokine balance and suppresses the hematopoiesis system, resulting in hematological abnormalities of the sufferer. ${ }^{2}$ The presence of secondary infections that accompany HIV infection, such as tuberculosis or side effects of antiretroviral drugs such as zidovudine (AZT) given, can also cause hematological abnormalities. $^{3}$

Hematologic abnormalities are one of the important prognostic markers for people with HIV/AIDS. 4 Hematological abnormalities, associated with an increased risk of morbidity and mortality in HIV patients. ${ }^{5}$ Anemia, thrombocytopenia or leukopenia, is the most common hematological abnormality in HIV patients.

Antiretroviral (ARV) treatment is standard therapy for people with HIV. ARV have been shown to successfully reduce viral replication, thereby increasing CD4 cell counts and inhibiting disease progression. ${ }^{5}$ However, several studies have shown that ARV use causes haematological abnormalities. ${ }^{6-8}$ In addition, the use of ARV is also known to increase oxidative stress in people with HIV.9 Nacetylcystein (NAC) is one of the antioxidant compounds that has been widely used as medicine. This compound can increase glutathione levels which play a major role in maintaining redox conditions in cells. Until now, there is only a few reseach discusses uses of NAC as an additional supplement for HIV patients undergoing ARV treatment. This study aims to determine the effect of NAC on hematological abnormalities that occur in HIV patients who are undergoing ARV treatment.

\section{MATERIAL AND METHOD}

\section{Study Design}

This study was a pilot study that uses a double blind randomized clinical trial design. The study was conducted in July 2019 - February 2020 at the Dr. Mohammad Hoesin Hospital, Palembang. 


\section{Subject}

The research subjects were HIV/AIDS sufferers who were treated at the Dr. Mohammad Hoesin Hospital Palembang during Juli until Agustus met the inclusion criteria, i.e.: all patients who had been diagnosed with HIV/AIDS, aged 2060 years, received anti-retroviral (ARV) drugs, and were willing to take part in the study by signing an informed consent form. Subjects were excluded from the study if they had a history of allergy to NAC, and took antioxidant drugs other than NAC during the study. Subjects were discontinued in the study if the subject dropped out of the NAC drug, died, side effects arose so that the giving of the NAC drug had to be stopped, and stopped participation before the study was completed. Based on these criteria, there were $32 \mathrm{HIV}$ sufferers who were the subjects of this study. Subjects were divided randomly into 2 groups, namely the placebo and NAC group. Each group is 16 people. Subjects in the NAC group were given capsules containing NAC at a dose of $3 \times 200 \mathrm{mg} /$ day for 12 weeks. Subjects in the placebo group were given capsules containing lactose at a dose of $3 \times 200 \mathrm{mg} /$ day for 12 weeks. This study was approved by the ethics committee of the Faculty of Medicine, Sriwijaya University and Dr. Mohammad Hoesin Hospital, Palembang (No. 552/kepkrsmhfkunsri/2019).

\section{Hematological Measurement}

Hematologic parameters namely $\mathrm{Hb}, \mathrm{Ht}$, erythrocyte counts, leukocytes, platelets and leukocyte counts were examined using the Sysmex XN 1000i Hematology Analyzer, with DCL Cellpack reagents. The sample used was the subject's venous blood. For each study subject, blood was drawn twice, at the beginning of the study / before the treatment and after the treatment ended. Based on WHO criteria, subjects were declared to suffer from anemia if they had a $\mathrm{Hb}$ level of less than $13 \mathrm{gr} / \mathrm{dL}$ for men and less than $12 \mathrm{gr} / \mathrm{dL}$ for women. Subjects were declared to have thrombocytopenia if their platelet count was less than 170.000 cells $/ \mu \mathrm{L}$; thrombocytosis if the platelet count is more than 396.000 cells $/ \mu \mathrm{L}$, leukopenia if the number of leukocytes is less than 4.730 cells $/ \mathrm{mm}^{3}$ and leukocytosis if the number of leukocytes is more than 10.800 cells $/ \mathrm{mm}^{3}$.

\section{Statistical Analysis}

The statistical analysis used mean, standard deviation, independent T test or Mann Whitney and dependent T test or Wilcoxon. The test results are statistically approved if the $\mathrm{p}$ value $<0.05$.

\section{RESULTS}

\section{General Characteristics}

Most research were male $(81,25 \%)$ with age range of 31 40 years $(50 \%)$, had secondary education $(43,75 \%)$ and worked in the private sector $(62,5 \%)$. The majority of subjects involved in this study were stage 1 HIV sufferers without comorbidities and had only been on ARV treatment for less than 1 year.

\section{Hematological Parameters}

$\mathrm{Hb}$ levels in the placebo and NAC group before treatment were higher when compared to $\mathrm{Hb}$ levels after treatment, but not significantly. However, the range of minimum and maximum values in the placebo and NAC groups after treatment was higher than before treatment. In contrast to $\mathrm{Hb}$, erythrocytes and leukocytes count in the placebo and NAC groups before treatment, was lower when compared to erythrocytes count after treatment. Ht levels and platelet count in the placebo group before treatment was lower than the Ht level and platelet count after treatment. The opposite was found in the NAC group, where Ht levels and platelet counts before treatment were slightly higher when compared to levels after treatment, but were not significantly different (Table 1 ). Furthermore $\mathrm{Hb}$ and $\mathrm{Ht}$ levels, erythrocytes and leukocytes count in the NAC group after treatment, was higher when compared to the placebo group, although it was not significantly different (Table 1).

Table 1: Characteristics of Hematological Parameters

\begin{tabular}{|c|c|c|c|c|}
\hline \multirow{2}{*}{ Parameters } & \multirow{2}{*}{$\mathbf{N}$} & \multicolumn{2}{|c|}{ Mean \pm SE $/$ Median (Min-Maks) } & \multirow{2}{*}{$\boldsymbol{P}$} \\
\hline & & Plasebo & NAC & \\
\hline \multicolumn{5}{|l|}{ Hb level } \\
\hline -. Before & 16 & $14,85(9,5-16,5)$ & $15,00(8,7-16,8)$ & $0,724 c$ \\
\hline -. After & 16 & $13,9(12,3-17,0)$ & $14,9(11,7-16,9)$ & $0,724 \mathrm{c}$ \\
\hline$p$ Before vs After & & $0,518 \mathrm{a}$ & $0,737 a$ & \\
\hline \multicolumn{5}{|l|}{ Erythrocytes Count } \\
\hline -. Before & 16 & $4,31 \pm 0,19 \times 10^{6}$ & $4,66 \pm 0,19 \times 10^{6}$ & $0,213^{\mathrm{d}}$ \\
\hline -. After & 16 & $4,55 \pm 0,14 \times 10^{6}$ & $4,68 \pm 0,15 \times 10^{6}$ & $0,538 \mathrm{~d}$ \\
\hline$p$ Before vs After & & $0,140^{\mathrm{b}}$ & $0,813^{\mathrm{b}}$ & \\
\hline \multicolumn{5}{|l|}{ Ht level } \\
\hline -. Before & 16 & $40,68 \pm 5,83$ & $44,50(27-50)$ & $0,184 \mathrm{c}$ \\
\hline -. After & 16 & $41,62 \pm 4,36$ & $42,06 \pm 1,07$ & $0,468^{\mathrm{d}}$ \\
\hline$p$ Before vs After & & $0,366^{\mathrm{b}}$ & $0,815^{\mathrm{a}}$ & \\
\hline \multicolumn{5}{|l|}{ Platelet Count } \\
\hline -. Before & 16 & $262.000(190.000-419.000)$ & $260.000(156.000-367.000)$ & $0,867 \mathrm{c}$ \\
\hline -. After & 16 & $271.625(174.000-445.000)$ & $259.000(198.000-487.000)$ & $0,780^{c}$ \\
\hline$p$ Before vs After & & $0,485^{a}$ & $0,127 \mathrm{a}$ & \\
\hline \multicolumn{5}{|l|}{ Leukocyte Count } \\
\hline -. Before & 16 & $6.083 \pm 423$ & $6.600 \pm 468$ & $0,419^{d}$ \\
\hline -. After & 16 & $6.710 \pm 508$ & $7.091 \pm 409$ & $0,564 d$ \\
\hline$p$ Before vs After & & $0,275^{\mathrm{a}}$ & $0,265^{\mathrm{a}}$ & \\
\hline
\end{tabular}

Exp: a $p$ value uses the Wilcoxon test; ${ }^{b}$ the $p$ value uses the paired T test; ${ }^{c} p$ values using the Mann Whitney test; ${ }^{d}$ Value of $p$ using the unpaired T test. All tests perform at $\alpha 5 \%$. 
Based on the WHO criteria above, before treatment there were 5 subjects suffering from anemia, 3 in the placebo group and 2 in the NAC group. The giving of NAC can reduce the degree of anemia from moderate to mild (Figure 1). In addition to reducing the degree of anemia, giving of NAC can also improve the condition of thrombocytopenia, leukopenia and lymphopenia in the subject. Although in the placebo group there also appeared to be improvement, but the addition of NAC seemed to be able to increase the effectiveness of the improvement that occurred (Figure 2).

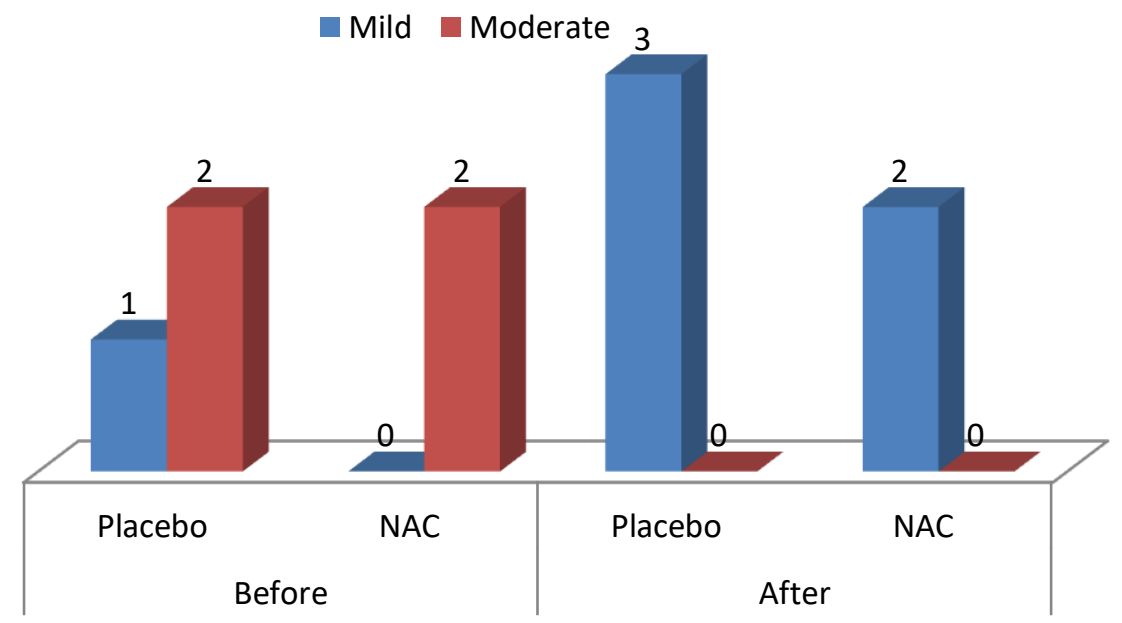

Figure 1: Anemia profile in placebo and NAC group before and after treatment.
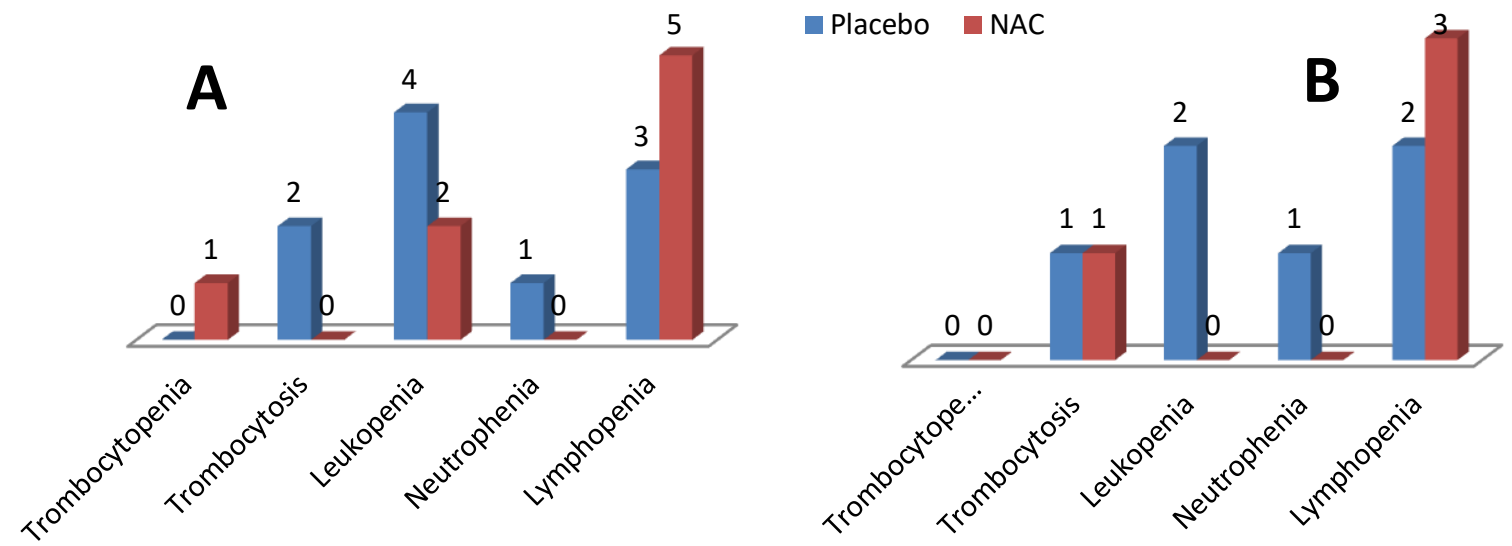

Figure 2: Hematologic abnormalities in the placebo and NAC groups

Note: (A) Before treatment; (B) After treatment.

\section{DISCUSSION}

In patients with HIV, various hematological disorders can be found that can act as independent predictors of the mortality and morbidity of sufferers. ${ }^{10}$ Some of the most common abnormalities include anemia, thrombocytopenia and leukopenia. ${ }^{11}$ This is due to decreased ability of the bone marrow to produce blood cells, resulting in deficiency nutrition, and disorders of the immune system of people with HIV.12-14

In this study, it was known that most subjects had normal hematological parameters. The mean $\mathrm{Hb}, \mathrm{Ht}$, erythrocyte, leukocyte and platelet counts in this study were still within normal limits. There was no difference between the mean levels of some of these parameters, before and after treatment (Table 1). This is certainly not surprising, because all subjects have received ARV treatment. In accordance with the research of Geletaw et al.,5 that the giving of antiretroviral drugs can improve hemotological abnormalities that occur in people with HIV.
The giving of NAC did not have a significant effect on $\mathrm{Hb}, \mathrm{Ht}$ and erythrocyte counts (Table 1). This is because the subject is an HIV sufferer who has received ARV, so the levels of these parameters in most patients, have been in normal conditions. Interestingly, giving of NAC to subjects suffering from moderate anemia can improve their condition. After administration of NAC, the subject's condition became mildly anemic (Figure 1). This seems to be related to the role of NAC as a GSH precursor. Several previous studies have shown that GSH in HIV sufferers has decreased significantly. ${ }^{15-17}$ Other studies conducted by Wagiallah et al.,18 show that a reduction in GSH has a significant effect in reducing hemoglobin levels, thus causing anemia. Provision of antiretroviral drugs in people with HIV, indeed proven able to significantly increase GSH levels, but not as high as GSH levels in people who do not suffer from HIV. ${ }^{19}$ Giving of NAC, is expected to help increase GSH levels in HIV patients who are given ARV, so that it can help improve the degree of anemia subject.

Like $\mathrm{Hb}$ levels, platelet counts are also affected by HIV infection. In this study, samples with thrombocytopenia 
and thrombocytosis can be found, although the majority of samples have platelet counts that are still within normal limits. Giving of NAC can increase the platelet count in samples with thrombocytopenia, so that the platelet count is within normal limits (Figure 2). Unfortunately, there is only 1 sample of patients with this condition, so it cannot be concluded whether the effect is indeed caused by NAC or other causes. Therefore, further research is needed with a larger number of samples to find this out.

According to Katemba et al.,11 leukopenia is also a disorder that is found in many people with HIV. In line with this opinion, in this study also found that there are subjects with leukopenia, amounting to 6 people. Leukopenia in people with HIV is caused by a decrease in the number of CD4 + T lymphocytes and NK cells, which are part of leukocytes, due to viral activity. ${ }^{11}$ Giving of NAC, can increase the number of leukocytes in subjects with leukopenia so that the number becomes normal (Figure 2). Interestingly, NAC was also able to increase the number of lymphocyte cells in subjects with lymphopenia (Figure 2). Lymphocytes are the cells most affected by HIV infection. Therefore, these cells usually experience a very significant decrease during infection. The giving of antiretroviral drugs can reduce the amount of virus significantly, thereby reducing the rate of apoptosis in lymphocyte cells. ${ }^{20-22}$ The giving of NAC as an additional supplement to HIV sufferers, seems to be able to increase the effectiveness of ARV given, especially in subjects with lymphopenia after receiving ARV. It also seems to be related to the ability of NAC as an antioxidant that can inhibit the activity of ROS molecules formed in leukocyte cells during infection, thereby increasing cell viability and decreasing apoptosis that occurs. ${ }^{23-24}$

\section{CONCLUSION}

NAC administration can reduce hematological abnormalities in HIV patients undergoing ARV treatment, althougt still need to be studied further.

\section{Acknowledgement}

Authors are thankful to Dr. Muhammad Hoesin Palembang, for providing facilities to carry out our research.

\section{REFERENCES}

1. Parinitha SS, Kulkarni MH, "Haematological Changes in HIV Infection with Correlation to CD4 Cell Count" Australian Medical Journal, 2012; 5(3):157-162.

2. Johannessen A, Naman E, Gundersen SG, Bruun JN "Antiretroviral Treatment Reverses HIV-Associated Anemia in Rural Tanzania" BMC Infect Dis, 2011; 11(190):1-9.

3. Lemarroy CCR, Flores-Cantu H, Calderon-Hernandez HJ, Diaz TMA, Villareal VHJ "Drug-Induced Haemolysis, Renal Failure, Thrombocytopenia and Lactic Acidosis in Patients with HIV and Cryptococcal Meningitis: A Diagnostic Challenge" Int J STD AIDS, 2015; 26(14):1052-54.

4. Emuchay CI, Okeniyi SO, Okeniyi JO "Correlation Between Total Lymphocyte Count, Hemoglobin, Hematocrit and CD4 Count in HIV Patients in Nigeria" Pak J Biol Sci 2014; 17:5703.

5. Geletaw T, Tadesse MZ, Demisse AG "Hematologic Abnormalities and Associated Factors among HIV Infected Children Pre and Post Antiretroviral Treatment, North West Ethiopia" Journal of Blood Medicine, 2017; 8:99-105.

6. De Jesus E, Herrera G, Teofilo E "Abacavir versus Zidovudine Combined with Lamivudine and Efavirenz, for The Treatment of Antiretroviralnaive HIV-Infected Adults" Clin Infect Dis 2004 39(7):1038-46.

7. Lorna A, Fatoumata D, Fla K, Malatese K, Gueye RD, Aka E, et al "Anemia and Zidovudine-Containing Antiretroviral Therapy in Pediatric Antiretroviral Programs in The Iedea Pediatric West African Database to Evaluate AIDS" J Int AIDS Soc, 2013; 16(1):1-8.
8. Moyle G, Sawyer W, Law M, Amin J, Hill A "Changes in The Efficacy of Thymidine Analog-Based HAART: A Meta-Analysis of Six Prospective, Randomized, Comparative Studies" Clin Ther, 2004; 26(1):92-7.

9. Sharma B. Oxidative Stress in HIV Patients Receiving Antiretroviral Therapy" Current HIV Research, 2014; 12(1):13-21.

10. Bhowmik A, Banarjee P "Hematological Manifestation in HIV Infected Children" Journal of The College of Physiscians and Surgeon, 2015; 25(2):119-23.

11. Katemba C, Muzoora C, Muwanguzi E, Mwambi B, Atuhairwe C, Taremwa IM "Hematological Abnormalities in HIV Antiretroviral Therapy Naive Client as Seen at an Immune Suppression Syndrome Clinic at Mbarara Regional Referral Hospital, Southwestern Uganda" Journal of Blood Medicine, 2018; 9:105-10.

12. Ogbe PJ, Idoko OA, Ezimah AC, Digban KA, Oguntayo BO "Evaluation of Iron Status in Anemia of Chronic Disease Among Patients with HIV Infection" Clinical Laboratory Science, 2012; 25(1):7-12.

13. Ezeonwu BU, Ikefuna AN, Oguonu T, Okafor HU "Prevalence of Hematological Abnormalities and Malnutrition in HIV-Infected Under Five Children in Enugu. Nigerian Journal of Clinical Practice, 2014; 17(3):303-308.

14. Fan HW, Guo FP, Li YJ, Li N, Li TS "Prevalence of Thrombocytopenia among Chinese Adult Antiretroviral Naive HIV Positive Patients" Chinese Medical Journal 2015; 128(4):459-64.

15. Banarjee A, Zhang X, Manda KR, Banks WA, Ercal N "HIV Proteins (Gp120 and Tat) and Methamphetamine in Oxidative Stress Induced Damage in The Brain: Potential Role of The Thiol Antioxidant N-Asetilsisteine Amide" Free Radical Biology \& Medicine, 2010; 48(10):1388-98.

16. Ivanov AV, Vladimir TVE, Olga NI, Sergey NK, Elizaveta SS, Birke B, et al "Oxidative Stress During HIV Infection: Mechanisms and Consequences" Oxidative Medicine and Cellular Longevity, 2016; 2016:1-19.

17. Monroy N, Herrero L, Carrasco L, Gonzalez ME "Influence of Glutathione Availability on Cell Damage Induced by Human Immunodeficiency Virus Type 1 Viral Protein R" Virus Research, 2016; 213:116-23.

18. Wagiallah H, Mohammed A "The Effect of Oxidative Stress on Human Red Cells Glutathione Peroxidase, Glutathione Reductase Level, and Prevalence of Anemia among Diabetics" North American Journal of Medical Science, 2011; 3(7):344-7.

19. Basey SBC, Asemota EA, Okoroiwu HU, Etura JE, Efiong EE, Inyang IJ, et al "Glutathione, Glutathione Peroxidase and Some Hepatological Parameters of HIV Seropositive Subjects Attending Clinic in University of Calabar Teaching Hospital, Calabar, Nigeria. BMC Infectious Diseases, 2019; 19(944):110.

20. Badley AD, Pilon AA, Landay A, Lynch DH "Mechanisms of HIV Associated Lymphocyte Apoptosis" Blood, 2000; 96(9):295164.

21. Scheller C, Jasoy C "Syncytium Formation Amplifies Apoptotic Signals: A New View on Apoptosis in HIV Infection in Vitro" Virology, 2001; 30:48-55.

22. Treitinger A, C Spada, IY Masokawa, JCV Verdi, MVDS. Silveira, MC. Luis, et al "Effect of $\mathrm{N}$-asetilsistein on Lymphocyte Apoptosis, Lymphocyte Viability, TNF- $\alpha$ and IL-8 in HIV Infected Patients Undergoing Anti-Retroviral Treatment" Brazilian Journal of Infectious Disease, 2004; 8(5):363-71.

23. Dobmeyer TS, Stephan F, Jurgen MD, Stefan AK, Bernhard R, Dieter H, et al "Ex Vivo Induction of Apoptosis in Lymphocytes is Mediated by Oxidative Stress: Role for Lymphocyte Loss in HIV Infection" Free Radical \& Medicine, 1997; 22(5):775-85.

24. Vijayan KKV, Krithika PK, Srikanth PT, Luke EH "Pathophysiology of CD4+ T Cell Depletion in HIV-1 and HIV-2 Infection" Frontier in Immunology, 2017; 8(580):1-8. 